\title{
2. IPOSTASES OF THE CHOREOGRAPHIC DIALOGUE
}

\author{
Cristina Todi ${ }^{153}$
}

\begin{abstract}
The analysis of the aesthetic face of dance brings to our forefront the fascination for the movement on many artists who experienced the movement and, above all, explored the possibilities of kinetic art or movement movement. In its most elevated form, dance contains not only this element but also the infinite richness of human personality. It is the perfect synthesis of the abstract and the human, of mind and intellect with emotion, discipline with spontaneity, spirituality with erotic attraction to which dance aspires; and in dance as a form of communication, it is the most vivid presentation of this fusion act that is the ideal show.
\end{abstract}

Key words: Arts, ballet, dance, dialogue, aesthetic

\section{Introduction}

\section{The Evolution of the Syncretic Dialogue between Choreography, Theatre, Music, Literature and Visual Arts}

We shall initiate an approach of the discourse regarding the historical evolution of choregraphic dialogue, even from the age when this artistic genre started to assume clear contours, rather from the $17^{\text {th }}$ century. Without excluding the importance of the previous periods in history, the $17^{\text {th }}$ and the $18^{\text {th }}$ centuries are considered to be the starting points of dance for amusement. This was often dedicated to ceremonies or entertainment. In approaching these moments, the increased attention towards the aesthetic expression and the manner in which beauty was intensified, sometimes even at the expense of the real, is notable. Moreover, the technicality under which theatrical ballet was formulated in its demonstrative forms, full of technical charge, although arid in ideas or expression that reach the sensitive cords of the viewer. The combinations of not too complicated steps prevailed, sometimes, even at the limit of an automatic mechanism. The entrées full of effects, with sensational elevations, as well as the succession of certain variations skillfully danced, highlighted by the wavy movements in the moments full of brightness of the Legatos reach virtuosity through Auguste Vestris ${ }^{154}$. These awarded him a continental fame.

In the first half of the $18^{\text {th }}$ century, opera becomes the most valued representation, and ballet its most shinning part. At that moment, countless changes which overturned conceptions, practices and recipes for an undisputed success emerged which determined dancers and ballet maestros to pursue speciality studies. If at the beginning of the governing of Ludovic the $14^{\text {th }}$, an excellent dancer and lover of grandeur, the Dance Academy was created,

\footnotetext{
${ }^{153}$ Lecturer PhD., „George Enescu” National University from Iaşi, Romania, email: cristinatodi67@gmail.com

${ }^{154}$ August Vestris (1760-1842) is part of a renowned family of dancers, his father being Gaetan Vestris
} 
subsequently, the Opera Academy was founded, which offered ballet the framework and the means through which it became the most voluptuous and admired representation dance.

A new artistic trend, from which the French Classicism shall build, envisaged the return to nature and order principles, measure and balance imposed by reason. The Academy, created a scientific choregraphy, through which ballet maestros and dancers subjected to reason the processes used, the dance form and the ballet theme. The artist must observe nature, but not accept it as spontaneous and exuberant, but represent it after countless purification operations and in forms that could satisfy the exigencies of intelligence. The audience requested more a mathematical truth than poetry. Painter Nicolas Poussin stated " My nature compels me to search and love well-organized things, running away from confusion which is to me as contrasted and an enemy as the light is to deep darknesses" $" 155$.

The dance maestros in the Academy, such as Charles Beauchamps, Jean Picquet or Hilaire d'Olivet, did not accept the exuberant dance, in its original, popular forms, movements and gestures that did not pass through the filter and control of reason. The ballet technique has thus fixed itself certain classical norms. The following were admitted as fundamental positions, the opening of the legs in the exterior with 90 degrees and the 5 good positions (in contrast with the 5 false ones) which were executed in a circle of approximately half of metre. The high leap and a more exact contouring of the steps had already been adopted. In terms of dynamism and purpose, theoreticians and practicians distinguished three categories of dance, included in academic canons and which corresponded with tragedy, comedy and pastoral.

The serious dance had a proportionate and measured drawing with elegant forms and graceful movements. The men's costume for this genre was luxurious and bulky, and the women wore large and long crinolines, the point of the shoe barely being observed under it.

The comic dance, was characterised by certain folk characteristics, more zest and freedom in movements. The interpreters added to the costume certain accessories, such as garlands, baskets or wreaths, which completed the clothing expressiveness.

Demi-character dances were reserved for ballets with fantastic or mystical subjects, or were used in pastorals. The fact that at very close intervals speciality books were written and means to write down choreographic movements and steps were searched, prove that the number of those interested in the technical issues of classical dances was increasing and that the desire to exercise the profession of servant of choreographic art was spreading. In order to come to their help, in 1713, two years before the death of Ludovic the $14^{\text {th }}$, a regulation emerged by which the Opera School of Dance, with free education,

${ }^{155}$ Wiliam Fleming, Arte şi idei, vol.II., translation by Florin Ionescu, Editura Meridiane, Bucharest, 1983, p. 72 
was founded. At the same time, pantomime was also developed, a show genre which used mimic, gestures and attitudes, without using dance steps based on the strict rules of classical ballet.

After the death of Ludovic the $14^{\text {th }}$, the development of manufactures and trade allowed the consolidation of a dynamic and prosperous bourgeoisie. The stormy French society began to evolve towards more free and gallant, more delicate, superficial and voluptuous forms of life. The titles of some of the opera-ballets of composer Andre Campra are illuminating: L 'Europe galante (1697), Le Carnaval de Venise (1699), Les Fêtes venitiennes (1710), or Les Amours des Dieux (1729).

At the same time, a change in the social position of the people was also occurring, by which the canons of classicism had kept it outside the limits of beauty. People rising from the lower classes by means of fortune and talent, now requested to participate in the lifestyle of the nobility. In architecture, painting, decorative arts and everywhere, topics, genres, attitudes who in the past had been considered worthless were rising and being admired and imitated. In choregraphy, the leap dance, previously seen as vulgar, thus became modern, removing the noble ones, with the measured steps.

Art no longer addressed to reason, but to the senses and the soul. Theoreticians such as superior Jean Baptiste Du Bos supported this trend, which is also sympathized by the musicians of the time. Rameau stated that music must speak to the soul ... No judgement can be done on music, but in relation to the hearing, and reason has no authority unless it is attuned to the ear. The spiritual evolution of the society and ballet, for which Rameau composed, needed freedom. Besides, Enlightenment thinkers Diderot, Rousseau, Voltaire, were amongst the top promoters of the new social and aesthetic trends.

But ballets in general did not have the formal cohesion to which they had reached in the previous century; they lacked a sufficiently deep contour, due to certain large passages of solo and choir arias that they contained as absolutely necessary parts. Cahusac, trying to delimit the genres, defined ballet as an entertainment with song and dance, which prepares an action, while in the opera, the action attracts entertainment. Plutarc, regarding ballet, stated that it is a mute conversation, an eloquent, living picture, which is expressed through movements, figures and gestures so different, as the sea makes waves during winter tides.

Thus, Rameau adopted the suite manner, in The Gallant Indies or Supplement to Bougainville's Voyage ( Les Indes galantes ou Suplément au Voiyage de Bougainville 1735), with the subtitle of heroic ballet, consisting in a succession of independent scenes which were carried out in far away lands and the fashion of exotism was exploited, resembling a great show magazine. Each act in particular was, however, a unit, in which the voices, the orchestra, the ballet and the enactment were coordinated with an amazing cohesion. He created a genuine glorification of dance and in his scenic creations everything was 
danced: the mystical exaltation - the Inca scene from The Gallant Indies (Les Indes galantes), the hate (act IV from Zoroaster), sadness or happiness, the fights (Castor and Polux) and oracles as in Hébé's Feasts (Fetes d'Hébé). Rameau, thus assumed amazing progresses achieved in that period by the dance technique and the more and more emphatic tendency of male and female dancers towards virtuosity. For this purpose, he, similar to other composers, must write for M-llé Sallé a passepied ${ }^{156}$, to Dumoulin a musette ${ }^{157}$, for Camargo a tambourine $^{158}$, and for Dupré a passacaille $e^{159}$, as each great dancer could better execute art and physical characteristics in that dance. Alternatively, the interpreters' virtuosity determined the creation of certain new gymnastics methods of the leap and preoccupations with the visual harmony of the steps, gestures and lines, the en dehors Technique, created by Italians, was adopted by French dancers and opened for the dance the path to the progresses in the modern age.

Amongst the illustrious dancers of the age, the first place is detained by Marie Sallé ${ }^{160}$, common interpreter in Rameau's ballets. In 1716-1717, she played in London, at the Lincoln 's Inn Field theatre and in 1725 was employed by the son and heir of the great comedian and mime John Rich, with whom she completed the art of pantomime. Coming back to Paris, she made her debut at the Great Opera, on September $14^{\text {th }}, 1727$, with an extraordinary success at the Venetian Feasts (Les Fetes venitiennes). Her noble and spiritual features were woven with a supple and voluptuous dance, executed in fine lines and agile movements, but lacking leaps and hops. Marie Sallé whole-heartedly expressed loving and gentle feelings of youth; she replaced with a logical and ascending action the monotone and cold images, common in ballet.

Due to certain misunderstandings with the direction of the Paris Opera, she returned to London, where Voltaire called for her with flattering words: Splendid witch, if Paris has offended you, London lays at your feet. There, at Covent Garden, on February $14^{\text {th }}, 1734$, her own choregraphic creation with a serious subject, Pygmalion, having as costume a muslin tunic after the Greek fashion, which was happening for the first time in the history of ballet. Thus, she

\footnotetext{
${ }^{156}$ It is a dance from the $17^{\text {th }}-18^{\text {th }}$ century which comes from Bretagne. This term is also used to describe music. Passepieds occasionally appears in Handel's music (Suite No. 1 in F) or in J.S. Bach in Overture. Leo Delibes also wrote a passepied, as a musical part in order to play Le roy s'amuse by Victor Hugo. A somewhat modern example is the fourth and last concert of Claude Debussy, Suita bergamasque for piano, entitled Passepied.

${ }^{157}$ Dance inspired by the sounds of an instrument similar to a bagpipe.

${ }^{158}$ Tambourine, a dance from Provence. Tambourine as a concert play, is full of life, written in binary. JeanPhilippe Rameau wrote many of the parts of his creation in this style. The most renowned is tamourin in $m$ minor with a clavecin, from the opera of Les Fêtes d'Hébé (1739).

${ }^{159}$ Passacaglia is a musical form which comes from the beginning of the $17^{\text {th }}$ century, still being used by contemporary composers. Its nature is ussually low, being often, but no always, based on a bas ostinato. It is as an interlude between dances and songs. The first was found in an Italian source dated from 1606. Passacaglia is closely connected to chaconne. Until mid 20 century, dance composers used the terms chaconne and passacaglia without discrimination and the attempts to reach a clear distinction are arbitrary and historically unfounded.

${ }^{160}$ Marie Sallé was born in 1707 in a family of artists. She picked up the tricks of dance with Françoise Prévost $(1680-1741)$
} 
was executing two of the reforms that later concerned Noverre: interpreted an action ballet and modified the costume, expressing a more realist theatrical vision and a reforming will.

Hëndel, excited by her new style entitled by the admirers of the Hellenic style $^{161}$, wrote for her a ballet-opera Terpsichore (1734), aPasticcio Oreste with ballet scenes (1734), opera-ballet Ariodante şi Alcina (1735), where he merged dances with the choir into a dramatic action. Although there were not as radical as to bring a revolutionary change in the style of ballet-opera, the reforms of Marie Sallé were introducing as a central and climactic point a sole action to which all other actions were subjected. Marie Sallé retired from the stage in 1740 being considered a pioneer of bourgeois humanism in the art of dance and ballet. Her contemporaries often compared her to Camargo, not to state their resemblance, but to better distinguish them after the rule of contrasts.

Marie-Anne Cuppi Camargo (1710-1770), of Belgian origin, studies in Paris with the renowned dancer M-elle Prevost. She made her debut in 1726 rapidly becoming a powerful rival of Marie Sallé. Animated by the same innovative vivid aspirations, she used for the first time in the history of ballet, soft shoes, which had been imposed by her manner of dancing. She possessed a vigurous technique and her manner of executing entechats - as a man, said Voltaire, - surprised and excited the audience. Camargo revived an old form current in the $16^{\text {th }}$ century, entechat a quatre and introduced small batteries, as an echo of the countless mordent trills deeply used by the composers of the beginning of the $18^{\text {th }}$ century. Also starting from this dancer, a shorter dress began to be used, as this was imposed by her tituppy dance, which let one see the ankles.

Camargo retired from the theatre in 1734, however, as she was passionate about art, returned to the Opera in 1740, finally retiring in 1751 . The qualities that made her famous were purely artistic. She was not tall nor beautiful, her dancing was vivid, light, in high glee and glowing. Jetés battu, la royale, l'entrechat coupé, without rubbing, Camargo executed them with an extreme easiness. She was intelligent and chose an animated, active dance, which did not leave the spectator the time to notice her physique flaws. Although she was naturally sad and serious, on stage she spread joy. After she tuned up the audience with joy and delight, obtaining the highest applause, backstage, her features would resume the usual shade of sadness, her charm would disappear and the pleasant features of joy would erase in a second from the cheek. Louis Dupré, referred to as the Great Dupré, lead singer at the Paris Opera, was contemporary with these great dancers He executed a rare harmony of lines, and his fine and wavy movements, in perfect accord with the willowy performance of articulations granted him a heavenly image, which attracted the name of Dance Apollo.

${ }^{161}$ The dance style has an inspiration source the civilisation of Ancient Greece 
With all these spectacular renewals, ballet scenes abounded in various mythological ravines full of gods and quaint images, of cavalcades of nymphae and Faunus vested in the luxuriant style of the age. Interpreters were often covered in famous wigs and hemmed in the strict ostentation of the costumes and masks, as were constraint by the spectacular ritual of the age. The pompous enactments were executed in the ambiance of an arsenal of decorative elements meant to generate fabulous appearances and quaint effects. Although these did not serve the choreographic theme, they were used only for the creation of an apparent visual pleasure. The ballet dancers in their art also represented the technical formulae brought to the excess of mechanicity. This fustile waste of imagination, shall however fix the gazes possessed by the sense of measure and of the proportions of genuine arts. Stimulating the will of an active direction in the choreographic field, with a spirited reforming vision, the personality of Jean Georges Noverre (1727-1810) shall assert, who makes his spectacular concepts known in the creation Srisori despre dans și balete (Letters on Dancing and Ballets).

He is the one who brought a new concept in the art of ballet, reformed it and laid the foundation for modern choreography. Although his parents had predestined a military career, Jean Georges, pushed by an irresistible vocation, desired to become a dancer. He had as a choreography professor Louis Dupré, unparalleled dancer and renowned creator of ballets. As a student and subsequently as a professional, he often visited Marie Sallé, with whom he had lengthy discussion on the issue of dancing. Dupré facilitated for him in the spring of 1743 employment at the Comic Opera, then left to the capital of Prussia. He danced in Berlin, Drezda and Strasbourg. In 1750 he worked as a ballet maestro in Lyon and Marseille, and in 1754 he was employed at the Comic Opera in Paris.

During all these years he completed his education by reading Aristotle, Homer and Greek tragedies, but also acquainting himself with everything written in the area of theatre. He read Du Bos, Cahusac, Diderot and other Enlightenment thinkers, attended painters' workshops, museums and studied anatomy. Concerned with literary, aesthetic and philosophical ideas of his time, between his readings, a primary place was occupied by his paper with Louis de Cahusac De la Danse ancienne et moderne, presented in 1754. It was a paper pervaded by humanism and echoes from the cult of theatre that the ballet was disseminating on the $18^{\text {th }}$ century, that Noverre considered as necessary to the dancer as the study of chronology for someone who wants to write history. Cahusac's ideas about the progress of dance, enthused Noverre.

In 1775, Noverre left for London, called upon by the famous English actor, David Garrick. A close friendship had emerged between the two. In the library of his new friend, Noverre could read the works of learned actor and dance professor John Weavers: Anatomical and Mechanical Lectures upon Dancing (1721), Hisiory of Mimes and Pantotnimes (1728) and Essays towards 
a Hisotory of Dancing (1712). Returning to France with the name of The Shakespeare of Dance and reaching a matured view on dance, Noverre decided to proceed to a deep reform of the art he practised. In a memorandum to Voltaire, on September $1^{\text {st }}, 1763$, Noverre wrote: "For over six years since I have intended to give a new shape to dancing, I understood that it is possible to create poems in ballets; I left behind symmetrical forms, I associated mechanical movements of the feet and arms with those of the soul and with various and expressive features of the physiognomy; I removed the masks and adopted a more realistic and precise costume. I revived the art of pantomime, and the nature that I have taken as a rightful guide and model procured me the means to make the dance speak, to express all passions and the possibility to place it amongst imitative arts" 162 .

The extraordinary success obtained by his following papers, where he applied, as it is clear from the letter addressed to Voltaire, aesthetic ideas he had reached through readings, meditation and experience, determined Noverre to publish in Lyon, in December 1759 and Stuttgart in 1760, Lettres sur les arts imitateurs en general e sur la dame en particulier. Under the form of letters sent to an unknown person, Noverre builds one of the most important writings in the entire history of ballet. Starting from a critique of the choreographic show of his time, Noverre considered that a fundamental reform must begin with the first element of ballet, dancing about which Noverre said that it was the art of building gracefully and with precision and easiness, steps on the tempi and measures given by the music. Dance is the technical and virtue part, and the action executed through pantomime is the expressive side of ballet.

From Noverre's point of view, ballet must, similarly to poetry, have two parts, a qualitative and a quantitative one. However, ballet is also a painting or a succession of paintings unified by a subject. When it is composed well, ballet is a vivid picture of morals, customs, costumes and passions, where there is a degree of tension that words cannot touch or, rather, for which there are not words. This is where dancing comes in, and a step, a gesture, a movement and an attitude tell what nothing else could express. But pantomime does nothing else than to express through steps, gestures, movements and the expression of the physiognomy the situation and the feelings of each character.

Noverre considers that an action ballet must have an exhibition, a climax and a denouement, must be divided into acts and scenes and each of these must have a beginning, a middle and an ending. But above all else, there must be truth and artlessness in the action, nerve and energy in the paintings and a wellorganized mess where it is necessary. The relationship between tastefulness grace, is highly important, both being given by nature and together lead to the refining of the dancer. As on stage everything must speak, describe and go through the dancer's expressiveness, into the viewer's soul: feelings, passions.

\footnotetext{
${ }^{162}$ Jean Georges Noverre, Scrisori despre dans şi balete (Letters on Dance and Ballets), translation by Ion Ianegic, Editura Muzicală a Uniunii Compozitorilor din R.S:R., Bucharest, 1967, p. 27.
} 
Noverre imposes thus to the ballet maestro a difficult and complex task. After he/she had deepened his knowledge about the dance mechanism, he/she must dedicate his/her free time to the study of history, mythology, anatomy and poetry. Thus, each ballet can become a poem, written by a poet, the musician shall translate it into music and the dancer shall expose the ideas through gesture and energetically. If the ballet maestro is well-documented, if he/she frequents artists of all genres, but mostly the visual arts ones and if he/she professionally guides the student, his/he intentions shall be visible.

In March 1760, duke Karl Eugen von Württenberg, to whom Noverre had dedicated his theoretical paper about dancing, employed him as a ballet maestro at the court. Here, in the great hall of the Stuttgart Opera, where 4000 spectators would enter, he represented one of the most important ballets he had created: Medea and Jason, Orpheus and Eurydice, Hypermnestra, Marriage by Contest (Il matrimonio per concorso). He was then called back to Vienna as a dance maestro of the imperial court and as a ballet maestro at Burgtheater KärntnertorTheater. In 1774, Noverre was chosen as a member of the Dance Academy in Paris, also becoming a ballet maestro at the Opera, a competence that he desired very much. Due to the intrigues and of the obstruction of Jean Dauberval, lead dancer of the time, he was forced to quit, without managing to introduce the reforms that he had envisaged. However, he enacted at the Opera ballets AApelles and Campaspe, Galathea's Caprices, Horatius and, in cooperation with Wolfgang Amadeus Mozart, Nothingness (Les petits riens) and The Twin Wigs (Le Finte Gemelle).

After a period spent in England (1789-1795), he returns to France, continuing to be concerned with the evolution that ballet was going through. Observing that the tendency towards virtuosity of certain ballet dancers with a talent for pantomime had led to a degeneration of ballet into a mimed tragedy, Noverre said that the dancer must always adjust his steps on the music, and if he/she sometimes slacks into a free walk non mesuré, he/she betrays the art becoming a comedy mime; his/her performance maimed by this negligence does not present either the same interest or the same agreement. In that period, under the influence of his concepts, a highly talented constellation of male and female dancers had been formed: Sebastian Gallet, Frühmann, Laborie, des Hays, Bournonville, Didelot, Allard misses, Guimard, Heinel, as well as Jean Dauberval, Gardel and Le Picq, who were his favourite students.

The ballet was progressing and it was gradually freeing itself from the canons of the nobility who was in an obvious and rapid decay. But the choreographers could not decide on fully giving up the old recipes for success detached under the aegis of academic rules. In 1807, although old and tired, but continuing to be concerned by the issues of dance and ballet, Noverre published a new edition, in two volumes, of his paper Lettres sur les arts imitateurs en geénéral et sur la danse en particulier, where he introduced the letters addressed to Voltaire, to Dauberval, to a German princess and to other persons. In 1810 on 
October $24^{\text {th }}$, Noverre died, leaving behind him a life of vexation and genuine creation. He said about his achievements that: I made in dance in a revolution as striking and as lasting as the one made by Gluck later in music. My letters were, however, nothing than the frontispiece of the monument that I had intended to raise to action dance, named by the Greeks pantomime. His work is also vivid nowadays through the value of the ideas it contains and through the ardent, passionate and optimistic reforming spirit of its author. Noverre's reform contributed to the enrichment of the ballet show, to the advance of the choreographic technique, to a progressive orientation. He gave up the court costumes making thus the movement easier for the dancers, fought against conventional gestures, against the empty symmetry of lines or of stage groups, bringing more action and movement. Noverre's activity and theoretical writings have a distinct significance for the development of the art of dance and ballet. Excited, Voltaire wrote to him: I find that everything you do is imbued with poetry" [...] "You are a Prometheus!.

Although he was not actually the creator of action dance, having precurors amongst theoreticians, actors and ballet maestros such as: Voscius, John Weavers, Cahusac, Franz Hilferding van Wewen, Marie Sallé, Camargo, from whom he took over valuable suggestions, Noverre gave the principle of action dance the logical and accomplished form. He created the independent ballet show, as it is nowadays. From his passion for this art and its servants, he sketched in pages imbued with warmth and characterisations portraying the portret of various male and female dancers of the $18^{\text {th }}$ century. For instance, Dumaulin danced a pas de deux with superiority difficult to achieve: always gentle and graceful, sometimes a butterfly, other times a zephyr, one moment volatile, another faithful, he rendered with intensity all the degrees of feelings. The conclusion from all the works of Noverre is that, in order to achieve the sublime, the dancer must

divide his/her studies between the spirit and the body, granting them the same importance, as only nature can accomplish miracles, being always on top of art.

Other valuable dancers of the time also had significant innovative contributions, such as: Gaetano Vestris (1729-1808), son of August Vestris (1760-1842), Louis Duport (1781-1853), Jean Dauberval (1742-1816), Gasparo Angiolini (1723-1796), with the latter, who apart from the fact that he was a great dancer, he was also a great musician and composer, being able to state that the age of Noverre was ended. Action ballet shall gain an extraordinary momentum in the 19 century and shall exceed by far the principles and theories stated by Noverre and his descendants.

\section{Choreographic Dialogues in the Romantic Musical Show}

The Romantic musical show opened new horizons of expression, combining fantasy with action, rising to an unsuspected level until the previous century the interpretation of poetic experiences through song and gesture. In this 
entirely new space, creators found specific communication methods, means through which no matter how distinct they would seem, have common elements with the opera and ballet. Amongst these, slow movements, capable of detailing the psychological features of the characters, drew the attention of composers, either by creating the great vocal lyrical sections - the famous slow arias followed by rapid endings, named cabaleta, or of similar scenes in the Romantic dance, the famous adagios concluded with a powerful conclusion, usually identified with the so-called coda. For ballet, adagios are moments of maximum ingenuity of poetic and visual expression when interpreters can prove the virtuosity of having a grip on all their technical resources, but also the capacity to transmit the feelings that animate them. Here is why, similar to the great lyrical arias, the adagios of the great Romantic ballets have become some of the most representative moments of musical and choreographic art, justifying their existence within the show but also their autonomy as interpretative recitals pieces.

In the suite of famous adagios, the ballet Le corsaire by Charles Adolphe Adam, is amongst the first famous Romantic fragments. The history of this ballet is long, consisting of various revivals which added to the initial version of choreographer Joseph Masilier, new dimensions, especially after the revival of the work in the repertoire elaborated by Jules Perot and then, Marius Petipa. Actually, the greay adagio in the Le corsaire ballet, is actually the result of a synthesis in which musical ideas completed themselves through contributions to the partition of Adam, due to Cesare Pugni, Leo Delibes and Riccardo Drigo.

The same tap for the adaptation of the choreographic language, but with a complete loyalty to the original partition, is also represented by the history of one of the most representative Romantic ballets that also wear the signature of Charles Adolphe Adam, Giselle ${ }^{163}$, also composed in cooperation with SaintGeorges. In this ballet, the adagio in the second act becomes the prototype of Romantic nocturnal lyrical poetry, suggesting various choreographic renderings, which unify the gesture with music in a perfect synthesis ${ }^{164}$.

\footnotetext{
${ }^{163}$ Fantastic ballet in two acts, after a story by Vernoy de Salnt-Georges by Théophil Gautier, adapted by Jean Coralli. The music is composed by Adolphe Charles Adam, the decorum executed by Ciceri, and the choreography bears the signature of Jean Coralli and Jules Perrot. It is a show created at the Royal Academy of Music in Paris, where the absolute premier took place on June $28^{\text {th }}, 1841$. The main interpreters were Carlotta Grisi and Lucien Petipa, being a Romantic show par excellence, created especially for Carlotta Grisi. Entire generations of ballet dancers approached this role and many of them were established through it. The role of Giselle is one of the most complex roles, being considered for a ballet dancer what Hamlet is for an actor. The expressiveness and technique, make an undeniable duet, where one cannot be without the other. After Carlotta Grisi, the great stars of universal ballet who made a creation in this role were Pavlova, Karsavina, Olga Spesievseva, Alicia Marcova, Galina Ulanova, Margot Fonteyn, Lycette Darsonval, Yvette Chauvire, Tamara Toumanova etc. Amongst the interpreters of Albert, one can mention: Nijinski, Anton Dolin, Igor Yuskevici, Serge Lifar, George Skibine. Amogst all them, Serge Lifar detaches himself through the dramatism he managed to impress in the scenes in the second act. Giselle shall remain a show of high repute in the permanent repertoire of all ballet companies in the entire world

${ }^{164}$ The high intensity magical moment, where the most sensitive feelings of the spectator are touched is when we see the cemetery suffused in the pearl-like light of the moon and a tomb on whose cross is written the name of Giselle, and on the background a ruined chapel keeps guard near the desolate swamp. At midnight the villis
} 
Towards the end of the $19^{\text {th }}$ century, adagios, as an essential part of the great soloistic duets, become central points of interest in interpretation, which increases their artistic value in the evolution of the Romantic style. This is the case of the no less famous pas de deux in the second act of the Don Quixote ${ }^{165}$ ballet by Ludwig Minkus, authentic recital play. The twilight of the Romantic age also meant the age when the poetic expression of ballet reached genuine climaxes, gradually overcoming the encumbrances of the machinery in favour for certain genuine recitatives, in which, the succession of movements and attitudes reflected symbolic values. At the same time, music unifies these elements through the richness of melodics and harmony, by means of the variety of tones. An example for this purpose is the act of Walpurgis Night ${ }^{166}$ from Faust by Gounod, where the aesthetics of dance is essentialized, the adagio having the amplitude of a passion poem. In the adagio in the second act of Swan Lake ballet, but its lyrical function tips the scale, countouring the delicate climate of love confessions, while, in the music that the same genius Ceaikovski created for Sleeping Beauty ballet, the protagonists' duet in the second act, has the function of presentation and introducing the characters. The apparent lento

cortege appears with their queen Mirtha, who is ready to receive a young girl, to the fore. Albert, with his arms full of lillies enters the cemetery and draws close to the tomb of his beloved. The phantom of Giselle flies around him and disappears. Albert must die, because he had entered the cemetery during the night and Giselle asks Mirtha to spare him to no avail. Albert and Giselle embrace each other and launch into a dramatic dance in which the man's forces end up slowly-slowly and Albert would have died if the dawn would not have come to scatter the villis phantoms. Left alone, Albert collapses on the tomb of his beloved. Their love must have ended by death as there was an insurmountable abyss between them, the social class distinction and the antagonism of the two mindsets that could not reconcile. The expression of feelings and states of mind of the main characters is executed through a total merging of the movements and gestures of the two lovers.

${ }^{165}$ Don Quixote - Ballet show executed after the novel written by Cervantes. It is one of the first ballets having as subject the history of choreographic art. We owe the first execution to dancer and ballet maestro Frans Hilferding, who, in 1740 on the stage of Kamertor Theatre in Vienne performed the premiere of this show. Three years later, in Paris Joseph Bodin Boismortie represented an opera-ballet with the same subject. 70 years later, Jean Georges Noverre, ballet maestro at the Imperial Court of Vienne executes another Don Quixote. In 1798, in Berlin, choreographer Etienne Lauchery, sympathizer of Noverre's theories, presents a great pantomime ballet entitled Don Quixote at Camacho's Wedding. Camacho's wedding transforms until the end in Basilio's wedding. Thus, Louis Milon enacts it in 1801 at the Opera in Paris, and Charles Didelot, in 1808 at the Imperial Theatre in Petersburg. Next is a Don Quixote on the music of German composer Gahsisch at the Linden-Opera in Berlin on the choreography of Paul Taglioni. It is such a great success that the show gets top billing for two decades. From 1869 until the end of World War Two, the only Don Quixote who was ever executed on the music of Minkus and the choreography of Marius Petipa. But, performances with this show have also been in Paris, in 1947, where Aurel von Millos, created a short, psychological ballet, where only three characters are presented, the Knight, the Squire and Dulcineea. In 1949 in Berlin, Tatiana Gsovski enacts a great ballet on the music of Leo Spies, a show revived in 1969. Furthermore, Don Quixote on the music of R. Gherhard, in 1950 at Covent Garden in London, on the libretto and choreography signed by Ninette de Valois. In 1957, Don Quixote on the music of J. Doubrava, choreography of J. Nermuth. Then, the one on the music of Nicolas Nabokov, performed in 1965 by George Balanchine, in New York. In Romania, this show was enacted on the music of Ludwig Minkus, being included in the current repertoire of Romanian Operas in Bucharest, Cluj-Napoca, Iaşi, Timişoara and Constanţa.

${ }^{166}$ Walpurgia Night is a choreographic picture included in Faust opera by Ch. Gunod. Ample ballet, a show in show, which can also be performed independently. Walpurgia - the night before May $1^{\text {st }}$, when the witches in the entire world meet on Brocken Mountain - Herz Massif - in a coven scornful against Saint Walpurgia (in the Catholic calendar she is celebrated on May $1^{\text {st }}$, the former mother superior of Heidemheim Monastery. She was subsequently sanctified for her chaste life). 
of the choreographed discourse allows for the perfecting of details, and each gesture has its own meaning and a special dialogic significance.

We hope that we managed to decipher the different stages of the dialogue through dance, impossible to achieve in such an ambience. The $20^{\text {th }}$ century continued through several Neo-Romantic creations the line of these adagio sequences, genuine danced dialogues, through which protagonists share their emotions, fears and feelings. Amogst these, famous moments are remarkable which their substance recognize this area even beyond the border to the age, such as: love duet in the balcony scene in Romeo and Juliet ${ }^{167}$ ballet by Prokofiev, or the meeting between Spartacus and Flavia in the ballet of Avram Haciaturian, which are the glorious achievements of the history of the Romantic adagio, which become a status of poetry, of dreaming, of bliss and of joy, noble uplift of the soul between new horizons.

\section{References}

1. Fleming, W., (1983) Arte şi idei, vol.II., traducere de Florin Ionescu, Editura Meridiane, Bucureşti

2. Noverre, J. Ge., (1967) Scrisori despre dans şi balete, traducere de Ion Ianegic, Editura Muzicală a Uniunii Compozitorilor din R.S:R., Bucureşti

3. Todi, C., (2017) Originea dansului în spațiul european, Editura Artes, Iași

4. Todi, C., (2017) Dezvoltarea plasticității corporale a actorului prin studiul coregrafic, Editura Artes, Iași

\footnotetext{
${ }^{167}$ Romeo and Juliet is a four-act and ten-scene ballet. Libretto - L. Lavrovsky, S. Prokofiev, S. Radlov, after the homonym tragedy of W. Shakespeare. Music, Serghei Prokofiev, Scenografia - P. Viliams, and the production and choreography bear the signature of $L$. Lavrovsky. The absolute premiere took place on January $11^{\text {th }}, 1940$ at the M. Kirov Opera and Ballet Theatre in Leningrad. Main interpreters: Galina Ulanova, K. Sergheev, A. Lapuhov, R. Gherbek, E. Bisner, I. Savrov. In Bucharest, the show was enacted by choreographer Vasile Marcu, and the scenography was executed by Ofelia Tutoveanu with the premiere on March $30^{\text {th }}, 1960$. Main interpreters: Irinel Liciu, Amato Checiulescu, D. Bivolaru, Gh. Cotovelea, Ilie Matei, Tilde Urseanu, Eugen Mărcui, Ilie Suciu, Mihai Sorotky etc.In Cluj-Napoca, Romeo and Julie was enacted by ballet maestro Gabriela Taub at the Romanian Opera on October $18^{\text {th }}, 1961$, the show was executed through a collaboration of both ballets in Cluj, the one of the Romanian and Hungarian Opera, with the scenography signed by Valer Vasilescu. Main interpreters: Larisa Şorban, Zsigmond Francisc, Şipoş Margit, Aurel Mărgineanu, Fodor Tibor, Vas Gh. Marius Hubic and others. The second premiere in Cluj, also at the Romanian Opera in 1998 in the choreography of Adrian Mureşan. Scenography - Andrei Şchiopu. Main interpreters: Anca Opriş, Dan Orădan and others. In Iaşi, the premiere of Romeo and Juliet show took place at the Romanian Opera on February $21^{\text {st }}$, 2002 in the coreographic enactment of Gh. Stanciu, with the main roles played by Mona Moldovanu, Slavick Baltaga, Sergiu Cotorobai, Irina Botezatu and others.
} 